\title{
The Feminist Postmodern Ontology: The Case of Marianne Wiggins' John Dollar
}

\author{
Dr. Hazmah Ali AI-Harshan
}

Assistant Professor at the Department of Languages and Translation, Faculty of Education and Arts, University of Tabuk, Saudi Arabia.

Received: 05 Aug 2021; Received in revised form: 09 Sep 2021; Accepted: 15 Sep 2021; Available online: 21 Sep 2021 (C)2021 The Author(s). Published by Infogain Publication. This is an open access article under the CC BY license (https://creativecommons.org/licenses/by/4.0/).

\begin{abstract}
In the last few decades, postmodern thinking has transformed critical engagement with, the matters of social, literary and artistic "knowledge" across a variety of disciplines, from literary studies and the creative arts to essential areas of philosophy, Feminism and many other fields. This article discusses the intersection between postmodern thought concerning the construction of the subject and feminist notions of an authentic female ontology that is not wholly dependent on patriarchal and imperialistic "writings" of women. (It also suggests that the earlier feminist exploration of the female patriarchal subject may even have been the forerunner of notions of the postmodern constructed "self".)
\end{abstract}

Keywords - Postmodern Ontology, Marianne Wiggins', John Dollar, feminist thinking.

\section{INTRODUCTION}

The site for discussion of this feminist postmodern ontology is Marianne Wiggins' novel, John Dollar (1987), which largely concerns a group of people washed up on a desert island. Extensive reference is made to the archetypal fictional travel narrative, Robinson Crusoe and how Wiggins subverts this masculinist travel narrative. The article focuses in particular upon the two main protagonists in Wiggins' novel: the mixed-race child, Menaka (Monica; Monkey) and the widowed white school teacher, Charlotte, and their subversion of the marginalized white, patriarchal and colonial identity that is thrust upon them. More importantly, the novel charts the characters' movement towards an authentic ontology relating to their actual experience. Thus Wiggins' novel embodies the theory underpinning the feminist postmodern ontology - both in her narrative choices and in the (re-) construction of her two main female protagonists.

Long before the end of the twentieth century, writers and theorists were already redefining the postmodern ways in which literary texts could be used to provide alternative modes of fiction. In her 1987 article, "Beginning to Theorize Postmodernism" Linda Hutcheon argued that this postmodern impetus in literature and culture was a reaction to, and a rebellion against, conventional narratives and the values/ideologies that inform those narratives [ref]. A few years earlier, in The Postmodern Condition (trans. 1984 [1979]), Jean-Francois Lyotard had asserted that postmodernist ideas both question and subvert the grand/master narratives that lay claim to supremacy, universality or legitimacy [ref].And in a similar vein again, Feminist ideology had long prompted writers to reconsider the uses of language and subjectivity in their novels and other forms of literary production. At the end of the century, Lidia Curti (1998) persuasively argued that Postmodernism might even have been a consequence of feminist thinking, observing that, "it is important to remember that the "postmodern" weakening of a unitary, universal subject may have been brought about by the very existence of female and feminist thought." She argued that feminism "with its reference to a divided and plural subjectivity...has inspired and informed a great part of this contemporary sense of crisis (Postmodernism)" (3-6). Both movements, then, greatly impacted upon literary production.

The purpose of this paper is to engage with the concept of a feminist postmodern ontology; an ontology that problematizes the very concept of "experience". The word "ontology" is generally associated with the physical world of human experience or the lived world of 
immediate experience. It thus[precedes] the objectification of reality. Meanwhile, existential ontology claims a "return to the realities of lived experience" as opposed to the "vicious abstraction of reason from existence" (Schrag xii). It is a re-conceptualization of the world: man has his world with him, as we might say, in his preoccupations and concerns. To adopt Martin Heidegger's phrase "man's being is always a being-in-the-world." In other words, the world is never there without the human subject, and the human subject is never there without the world. Certainly, this is the ontological concept of the world from an existentialist perspective. Arguably, "the existential plight of man and woman under the condition of modern life", as Zygmunt Bauman observes, "[i]s strikingly different from . . . the old assumption--that free will expresses itself solely in wrong choices; rather, it is now assumed that individuals, while exercising their free will and making their choices, are likely to choose what is right and proper over what is wrong and evil" (Postmodern Ethics, 6). Yet, in spite of this focus upon individual free will, Postmodern writers are frequently called upon to represent a common or universal experience that transcends the individual ontological being. Can there be any escape from this normative universalism? Certainly, the author of John Dollar seems to have found some ways.

An ontology is a theory of reality within Cartesian systems of philosophy, 'being' is defined as comprising the body and the mind, with the physical connected with women and the mind with men, as well as the rational elements of mind associated with men and the irrational emotional components associated with women (Bordo, 1986). Feminist ontology is concerned with theorizing being and opposing Cartesian binary approaches to comprehending the body-mind-emotions connection. Bordo (1986) believes that reality is defined by two conflicting concepts maleness and femaleness.

Hekman (2003) argues for rehabilitating ontology, claiming that an ontological approach derived from the essential social context of human understanding permits Gadamer to provide ways of exposing the presuppositions that make knowledge possible, and provides tools at his disposal that postmodern theorists lack. Gadamer's emphasis on ontology is one part of his work that presents a counterpoint to postmodern nihilism. Gadamer's method to textual criticism is defined by his idea of ontology. Understanding, according to Gadamer, requires ontology: to be placed, to have a horizon, is to be someplace (Hekman, 2003).

The feminist postmodern ontology provides a key to understanding Marianne Wiggins' 1987 novel, John Dollar. Feminism and postmodernism together allow a woman writer like Wiggins to investigate the boundaries and margins of [society, home to womankind]. Where identity and subjectivity are constantly in flux, this fluidity can offer women a place of empowerment. Patricia Waugh also sees the ways in which both feminism and postmodernism affect the creation of women's literature:

Both are concerned to disrupt traditional boundaries: between "art" and "life," masculine and feminine, high and popular culture, the dominant and the marginal. Both examine the cultural consequences of the decline of a consensus aesthetics, of an effective "literary" voice, or the absence of a strong sense of stable subjectivity. (6)

Aesthetically, Postmodernism, can be a site of affirmation, freedom, and delight. The postmodern woman novelist is freed to investigate the margins [of society and culture] and the marginalized identity of women. Nancy Armstrong argues that the "modem individual" was "first and foremost a female" (66). Postmodern woman has been empowered to explore different means of expressing her "selves," in order to arrive at a suitable or bearable identity.

"Because language function is a means through which identity is established, it is an important facet of the feminist postmodern ontology". If an identity is constructed through language, then that identity, no matter how privileged or oppressed, is constantly shifting and in flux. Language is recognized as a site of self-fluidity and flexibility. Jean-Francois Lyotard argues that:

\begin{abstract}
A self does not amount to much, but no self is an island; each exists in a fabric of relations that is now more complex and mobile than ever before. Young or old, man or woman, rich or poor, a person is always located at "nodal" points of specific communication circuits...No one, not even the least privileged among us, is ever entirely powerless over the messages that traverse and position him. (15)
\end{abstract}

Lyotard discusses the position of identity or self as language acts upon it and the recourse a "self" can take. He explains that it is through "language games" that the individual can move and resist, in part, the "messages" that are passed through, and imposed upon, him (15). Postmodern theory, then, allows for any person, male or female, to resist the cultural messages imposed upon him or her. Thus, for a female writer, language can be seen as a means of empowerment that enables women to re-create the narratives of their lives to reflect their lived experience.

In reading Marianne Wiggins' John Dollar (1989), one is directly confronted with a novel that puts 
into practice the theories underpinning the feminist postmodern ontology highlighted above. Wiggins questions the certainty of the socially constructed female identity, and the language employed to define it. She highlights - and utilizes - the instability of language to destabilize the received (dominant) notion of ontological identity. The word "ontological" has no fixed meaning except that of "about being" - it must always have a qualifier Here, I have added the word "received" but you might prefer the Marxist term, "dominant". Wiggins" novel revolves around the question of what a postmodern feminist re-writing of Daniel Defoe's Robinson Crusoe (1719) would look like. Indeed, Wiggins explicitly connects her novel to the British classic. She writes:

Everyone who stepped ashore that day (except the bearers) had either read or heard the story of The Life and adventures of Robinson Crusoe so there was that, that sense of exhilaration which comes when one's le life bears a likeness to the fictions that one's dreamed. Plus there was the weighty thrill of bringing light, the torch of history, Into one more far-flung "reach of darkness." (69)

Yet in spite of the heavy-handed intertextuality, Wiggins has her own text go against the male master narrative. She calls attention to her practice of literary subversion in order to engage with a whole history of postmodern and feminist literary writing. Writing about the multiplicity of revised Crusoe narratives generated in the twentieth century - so including that of Wiggins -Ann Marie Fallon observes that "the proliferation of Crusoe is not a struggle between two potential alternative readings of Crusoe but really an altogether new way of mapping how we understand and read literature in motion across the globe." She concludes that "each revision he has come to mean something new again." (220). Thus it could be argued that Wiggins adopts the Robinson Crusoe's story as a way of participating in a long tradition of self-discovery about a female's struggle to enter into the social world.

Notably, women are almost completely absent in Defoe's very lengthy and very canonical Robinson Crusoe "The deficiency in the original - in which half of the world's population is ignored -is remedied in Wiggins' reimagining of the narrative in John Dollar through the centrality of her female protagonist."]Women subjects are essential to the development of the novel. Wiggins' phrase, "the fictions one's dreamed" emphasizes that there will be the ontological development of the female characters in John Dollar from patriarchally-constructed subjects to authentic subjects engaged with their own lived experience The author's focus on this kind of character development highlights her irresistible fascination with effective methods of constructing female history and preserving identity. As Karen Lawrence astutely observes, "Women writers of travel have tended to mistrust the rhetoric of mastery, conquest and quest that has funded a good deal of male fictional and non-fictional travel[writing]" (20). This may be interpreted as meaning that travel writing offers women writers a rich set of narrative possibilities in order to destabilize the validity of the privileged male subject and the consequent marginalization of the female subject.

The concept of journeying is central to the feminist postmodern ontology as expressed in Wiggins' John Dollar. There is a natural power noticeable in the act of leaving home (that is, in the act of leaving the private or female sphere for the public or male sphere of activity where re-making of self and fortune is possible).In itself, Robinson Crusoe has come to symbolize, in Ian Watt's words, the "modem myth of individualism." Watt has labeled Robinson Crusoe as "[t]he articulate spokesman of the new economic, religious and social attitudes that succeeded the counter-reformation" and a predictor of "those practical heroes, the empire builders"(xv). Watt argues that the appeal of Crusoe lies in his ability to represent the paradox of modern individualism. He is a self-sufficient capitalist individual. Likewise, Wiggins's John Dollar raises the possibility of a feminist's idea of "leaving home" for dominating territories as a kind of power and personal freedom and individualism. Sandra Gilbert and Susan Gubar maintain that British women who traveled abroad were among the first supporters of women's autonomy (40). Caren Kaplan has argued that in "leaving home," postmodern women can abandon racist narratives.

In this light, Wiggins creates a postmodern female, Charlotte Lewes, who reflects her woman's ontological identity in the margins. Charlotte's journey from conservative widow to liberated schoolteacher begins as she arrives the island: "[w] hat had previously defined her world now served to torment her, she went searching through their old books looking for some words of comfort and heard herself screaming in her head at the stupid heroines instead. She hungered for a different kind of story" (14). In Burma, she occupies a kind of open-walled shelter on the very edge of Rangoon. She experiences empowerment with the recompenses of self-expression and personal freedom. Her altered version of story is depicted in leaving London for distant lands. She lives amidst the open landscape on the island, alone and blind. The images of open landscape establish a sense of a challenge to ontological identity that subverts patriarchal traditions.

Journeying becomes a mode of escaping domestic roles and fleeing patriarchal language. This aspect of 
travelling enables women narrators [authors to seize the metaphor of Crusoe's travels and claim the metaphor of the journey per se as a space for female subjectivity. This is especially true of Wigginsin John Dollar. Throughout Charlotte and Menaka's journey to the island, their sense of self and their place in the world is revealed. The novel opens with Charlotte and Menaka on a cliff in England overlooking the ocean. They reflect the figures of Robinson Crusoe and Friday overlooking the sea, waiting for rescue. In Crusoe's story, there is stress on the barrenness of the island and its availability to be 'inscribed' by Crusoe. The act of observation is a move to integrate the island into the body and the psyche of the pioneer. However, very unlike Crusoe and Friday, Charlotte and Menaka do not speak; "They had done nothing. They looked at the sea year after year, they refused to forget, to look forward, look anywhere, but to sea" The assimilation of the island hints to Charlotte and Menaka's sense of well-being as females. Crusoe makes the familiar landscape unfamiliar and in doing so, places us as readers in a different relationship to this. Charlotte's imagining of the island is transforming what seemed familiar or at least realistic, into something altogether different.

The island is identical with the act of textual subversion. When the British men gather to decide which island they will rename in honor of George V, John Dollar says,

"[i]n all his years of reading charts he'd never seen a chain of coral islands whose appearance on a map came as close to looking, as these did, like seeds broadcast from a single pod each one the doppelganger of the others. Besides, he argued, the Andamans were still-evolving islands, their contours were always changing" (57).

Dollar's remarks are implying the necessity of a journey of exploration. The island is transformed from a place of depression, to a refuge for women's free will.

The dialectical relationship between the mixedrace Menaka and the white Charlotte teases out [OR highlights OR symbolizes] the issues of ontological gender identity post-First-World-War and beyond, within the language of the feminist postmodern novel. Arguably, Wiggins needs to highlight these issues because many Western feminists see the third-world woman as ignorant, poor, uneducated, tradition-bound, domesticated, familyoriented, victimized, and as symbolizing suffering and subjection whereas they see themselves as educated, modern and as having the freedom to make their own lives. As Me Leela Gandhi points out, the white European female frequently achieves authority at the expense of the "native" female subject (40). Menaka's construction in the text, as a silent, mixed-race woman, makes her a representation of suffering under both patriarchy and racial suppression. Her narrative is reduced to unstated sound "[t]he Indian found music, half- remembered, from her childhood and she sang, nonstop, as she groomed the corpse and set out on her journey" (4). Menaka's own subjectivity is only permitted to reflect her oppression and subjugation rather than to disclose a fluidity and fullness of being.

In her late-twentieth-century Robinsonnade, Wiggins creates tension similar to that surrounding the existential crisis of history and identity theorized above. As Nancy Peterson observes, "writing history...has become one way for marginalized peoples to counter their invisibility". (984) And it is in this light that Wiggins' fictionalized "history", John Dollar, portrays her two culturally diverse and contradictory female protagonists' struggle for survival. It is an apt, humane, postmodern and even feminist -project on her part to dispel notions of fixed ethnic identity and cultural history in a way that enables the marginalized subject to construct new ways of being and being perceived by the dominant that offers more choice, opportunity, and liberty.

Subverting the original Crusoe's master narrative, the marginalized Menaka is a speaking subject at the end of the novel. She can easily map the island but her friends are unable to understand her advice. She inhabits the island as a native; she is able to find the path. For example when twin schoolgirls, Sloan and Sybil are looking for a short road towards fresh water, Menaka(called Monkey by the other women) attempts to draw an accurate verbal map of the foot path to the river. Monkey's set directions conform to her vision of the jungle itself (though note that she accepts the over-writing of her subject hood, by her white companions even in her internal monologue). Menaka delivers her directions in almost poetical language rather than in scientific, rational discourse, though with an ontological directness that cannot be understood by the equally overwritten British females marooned with her. For Menaka knows two realities even if she is generally forced to live in the one that comprises the inauthentic colonial world. She has two worlds to draw upon; the white women have only one and they suffer accordingly:

Go down there, Monkey had said. It isn't far, she told them. Go to where the empty casks are hidden. Behind the biggest cask, the one with the red stripes on it they'll see a banana palm. Walk into the jungle so the 
banana palm is always right behind them. Walk while counting to a hundred and they'll see her first mark at the base of a tall tree. They'll know which tree it is because there is a parrot sitting in it. Then turn left. Walk straight along, keeping to the upward slope. If the ground goes downhill turn around and stay up on the highest part. After a while they'll find her second mark. Go straight but keep the sun at their left shoulder. They'll find the tree that weeps enjoyments. Beside it is an anthill. Next to the anthill is a log across a slimy part.On the other side of it turn right. Go straight again until they reach a big red boulder in the middle of an open part. Turn left. After that the jungle will get thick and all they have to do is go until the jungle curtain opens Then they'll see the river. (203-204).

Monkey describes the path to freshwater to the twin British schoolgirls but they cannot follow the directions. They simply crash through the jungle aimlessly and end up being swallowed by quicksand and eaten by ants. Their inability to follow "Monkey's" directions indicates a great gulf in understanding between "native" and "British" females. Menaka's identity remains integral integrated and a force of clarity and salvation, but the other girls - due to a void in their understanding and an inability to apply the rules of "civilization" to their current circumstances begin to turn into primitive, savage cannibals. In Gail $\mathrm{V}$ Dohrmann's words, "They behave no better than the cannibals who so traumatized them earlier; for all their education, sophistication, catechisms, religion, and manners - their civilization, in short - they are savage at the core." (71) Accordingly, the native female subject achieves authority at the expense of white/European female subject. Wiggins revises the image of the "third world woman" as an icon of suffering and inarticulate subjection. In short, in Wiggins' novel, Menaka becomes a witness to Charlotte's failure as an authentic? and realized individual. Wiggins may be seen to undermine the typical narrative relationship between white female subject and the (subject-ed, purportedly voiceless) subaltern.

Matters of authentic ontological identity and native history permeate this discourse, this story. Wiggins creates a novel which reflects the diversity and, oftentimes, diametrically opposed realities of Menaka's (Monkey's) life. Charlotte's temporary blindness and isolation on the island marks a transformation in her character as well as a shift in the plot development. She stays close to a stream and it is here that Monkey discovers her. The stream is the site of Charlotte's "re-vision" (seeing anew).Water represents salvation and rebirth. Like the revision of Robinson Crusoe, Charlotte's re-envisioning makes the familiar landscape unfamiliar. It places readers in a different relationship to the master-narratives. Charlotte's re-envisioning of the island reenacts the reader's experience of the novel, transforming what seemed familiar or at least realistic, into something altogether different. The reader encounters Charlotte just a few pages before the end of the novel as she recovers her sight. With the immediacy of present-tense narrative, the reader is told that she finds that the world she constructed in her mind's eye is significantly smaller: "[n]othing is as she had dreamed it. In her mind she'd made a different landscape, this one seems less real somehow, a geography in miniature" (211). The mudfish she thought she was eating turn out to be maggots. The giant waterfall turns out to be smaller than she had imagined. "The distance she had wandered must be very small indeed, she now considers" (210). Charlotte's passage is from liberated 'new woman' to silent witness. If Crusoe's journey is a journey to selfhood and narrative, Charlotte's journey seems to be towards silence and transformation.

Wiggins uses language as a means through which to establish ontological identity. She toys with the supposed connections between the ontological (real; concrete: actual) existence of land with the (abstract; contingent) construction of language. Wiggins goes on to review the way in which the British lay claim to land and people through the acts of naming and mapmaking. Menaka observes about the British, synecdochically conceived of as one male:

He eats and eats. He eats mountains and Ore. He eats diamonds and rubies, blue sky. He eats cities, chews names. He eats people. Her name was something a long time ago that the English had chewed from its whole state of Menaka into a word they said, 'Monica' into the status of 'monkey,' for short. He translated her person; he chewed and chewed (7).

The British are the cannibals in Menaka's account, remorselessly gorging on people and resources. She gives a description of a greedy British authority that "chews and chews". This British authority chews up both names and geographies. Yet, supposedly deficient in language, it is Menaka who finally speaks.

Actually, Friday-Crusoe depends on every possible 'gesture' or bodily sign of slavery to express his place in relationship to Crusoe. In fact, Crusoe immediately begins to teach Friday a variety of common nouns: "I likewise taught him to say Yes and No, and to know the meaning of them" (257). The successful imposition of a particular kind of language (and hence a particular kind of reality) - indeed, an inauthentic 
ontological identity - is both the outward and the inward sign of Friday's slavery. In Wiggins' novel, Menaka is only called "the Indian" and the words she actually speaks are represented in broken English: "[W]hile cleansing Charlotte's hair in the chamomile, the Indian surprised herself in song. It was not a pleasant noise at first, arising as it did from grief, but after several sounds of pure lament, the Indian found music, half-remembered, from her childhood and she sang non-stop, as she groomed the corpse" (2). She cannot tell the story of the island. She is afraid to share her stories with the white/European females on the island because they may laugh at her. Moreover, even at the end of the novel when she tries to tell Charlotte about the death of John Dollar she cannot bring herself to do it.

Wiggins' attempt to re-master a language of the island questions the certainty of the self, identity, and language. She highlights the instability of language and thus, by analogy, destabilizes the notion of a static female identity. When the British come ashore in the novel, in the long-established British colonial fashion, they rename the island. Once again the island is open to a different set of namings, and remappings of its old identity. The schoolgirls 'rename' the island again, mimicking their parents' habit of subjectivity. Gaby says: "I think we should have new laws. We should do what God did, we should Name Everything. We should make this map and name things - we should have a name for places" (115). Similarly, Crusoe refashions himself and the island through the imagination and language. Novak argues that Crusoe "transforms his island world through the agency of language, and particularly ... through a creative process of naming" (110). In making laws and giving names to places and things on the island, including himself, Crusoe both creates and assumes control over his island home. By renaming, "Crusoe assumes possession of him in the same way that Columbus assumed possession of the land by his naming" (117). Novaksees the act of naming as a means of Crusoe taking possession of Friday. Arguably, Wiggins' technique to rename comes from an aspiration to make the island conform to the girl's the fictional Gaby's authentic (OR constructed) ontological experience and to rebuild the sense of power that derives from the ability to name one's empowerment and one's ontological being.

We are told that, after the earthquake, the land "has swallowed itself" (111). The island is like a new territory. Wiggins makes clear that the catastrophic earthquake's disasters have has utterly changed the landscape of the island. The image trope represents the total absorption and engrossing annihilation of past experiences. She stresses exercising the girl's free will and making their choice. She transforms their individualism through representation.

The author's tendency to imagine and create her female characters' own reality reveals something of the nature of language. It involves an assembly of images and cultural constructs, as well as material practices and circumstances. The narrative choices Wiggins makes are central to her subversion. The text constantly shifts its narrative perspective - in both temporal and exegetic terms -these shifts highlighting the fluidity of form. The novel begins with Charlotte's death and then moves backwards in time to Charlotte's youth in London. Her journey starts from London, where she is defined as a widow, then she is labeled "schoolteacher", and finally she is revealed as a murderer of cannibalistic schoolgirls. Meanwhile, when the articulate Charlotte travels to Burma, her journey is marked by "sudden loss of language." We are told that

Of Bombay Charlotte would remember little because from the Heat there flowed the Lassitude. Her blood felt waxen. Docks, the mossy decadence of balconies and buildings, steamy streets, the beach, every detail of her landing and her passage through the city to Victoria Terminal coagulated. The very moments she'd dreamed of with excitement came to her through Lassitude as one whole single-sheet flocculent mass, a woolly, fleecy, opaque, blurred surrounding. After Lassitude there was the Sudden Loss of Language (Wiggins 20)

Charlotte becomes incoherent and unable to guide herself across the island; she literally loses the power of language. (The use of capital letters tells the reader that this is an important concept rather than just random words.) The moist climate first limits the movement of her body and then drains her ability to use language. Crossing water represents the loss of language as one cross over boundaries.

Franco Moretti argues that most nineteenthcentury British novels move continuously outwards: from village to the seaport to the ocean. Wiggins transforms this nineteenth-century trope of water into a schema in which to depict changes in the fictional subject's ontological identity, the transformation of [the inauthentic to authentic] self on the island. Even the lesser body of water, the stream on the island serves as a momentous border for Monkey's vision to draw the island. As was observed above, it is also the site of Charlotte's self-discovery at the end of the novel when her sight returns. She finds that the world she constructed in her mind's eye is significantly smaller: "Nothing is as she had dreamed it. In her mind 
she'd made a different landscape, this one seems less real somehow, a geography in miniature." (211) The mudfish she thought she was eating turn out to be maggots. Language is associated with seeing. It is a mode of revision (and re-vision), and water opens up new vision.

The novel terminates with a sense of veneer that echoes Charlotte's sense of individualism. It ends when Menaka finds Charlotte near the freshwater stream and guides her back to the spot where Nolly and Amanda have been eating John Dollar. Menaka sees that it is too late to rescue John, but she cannot bear to tell Charlotte:

When she thinks about that day she thinks about it from above as if she were made of smoke, she sees the way that Charlotte took her hand and made her heart feel whole again, as if it still were possible to feel some sort of love. She always sees them from above and she and Charlotte look so small, like tiny people who appear on the shore two tiny people, the sun at their backs, naked figures, a child and a woman, making their way on the sand toward the smoke on the hill, and they walk, Monkey sees, refusing to see what happened next: they walk and they walk and they walk and they walk and they walk, she believes. (214)

The two figures on the island represent a sisterhood affiliation that defies the dislocations of the rest of the novel. The statements, "Charlotte took her hand" and "they walk and walk," involve authentic connection and encounter. As Susan Stanford Friedman observes, "Such an explanatory power for feminism of this migratory geography of borders ...moves in two directions: the descriptive, delineating networks of existing syncretism in everyday life and the utopic, forging pathways of possible connection, affiliation, and reconciliation" (68). The novel ends with the image of a woman and child on the beach. The mother and child are seen from above; Menaka, here, revises her narrative position, seeing everything and yet refusing to see. The primitive - and yet eternal - image of mother and child removes racial difference; the two become the first inhabitants of the island again. This scene is in glaring contrast to the images of destruction and horror that inhabit the rest of the text. Wiggins establishes her metamorphosis as a postmodern feminist revisionist in an impressive new way.

In conclusion, Wiggins' John Dollar invokes the metaphor of Crusoe's journey in order tore-work it as a space for [debating] [writing] authentic female ontological subjectivity. In patriarchal Western literature - that serves to suppress, subjugate, and marginalize females' voices and subjectivities - woman spends almost her entire life isolated and confined within the domestic sphere and the home before moving out into the modern world. Journeying becomes a mode of escaping domestic roles and fleeing patriarchal language. Wiggins chooses to depict Charlotte and Menaka's ontological quests for selfhood rather than their "selves" as constructed by bourgeois social mores and the demands of capitalism/imperialism. The two characters do not fit into conventional patriarchal stereotypes; in a sense, they may be regarded as revolutionary 'realities'. Charlotte and Menaka's ontological freedom is judged in terms of their reactions to what happens on the island. They experience their condition and come to an inner realization. They recognize that they must free themselves from the abstract conventions and morality of patriarchal culture in order to become themselves. They affirm their free will. Charlotte realizes that she has been exiled from her former life and has no hope of being accepted into the social level for which she has been educated. Her life as a teacher challenges her freedom. She has identified (named; labeled) herself, as well as allowing the community to identify her. This positioning of the self has often been interpreted as the stance of a free woman. Identically, Menaka does not cast herself in the marginal position assigned to a marginalized woman. She refuses to exist on the margins of patriarchal rules. She subverts white/European ideology and power by establishing her ontological identity.

\section{REFERENCES}

[1] Alcoff, Linda Martín. "The Politics of Postmodern Feminism, Revisited."Cultural Critique 36 (1997): 527.

[2] Aranda, Kay. "Postmodern Feminist Perspectives and Nursing Research: a Passionately Interested Form of Inquiry." Nursing Inquiry 13.2 (2006): 135-143.

[3] Armstrong, Nancy. Desire and Domestic Fiction: A Political History of the Novel. New York: Oxford University Press 1987.

[4] Bordo, Susan. "The Cartesian Masculinization of Thought." Signs: Journal of Women in Culture and Society 11.3 (1986): 439-456.

[5] Cokal, Susann. "Marianne Wiggins and the Eight Daughters of Chaos: Narrating the Body (of) the Text." Critique: Studies in Contemporary Fiction, (1999), 40:2, 99-118, DOI: 10.1080/00111619909601567

[6] Curti, Lidia. Female Stories, Female Bodies: Narrative, Identity and Representation. New York: New York UP, 1998.

[7] Defoe, Daniel. Robinson Crusoe. Amazon Classics Edition: Kindle Edition, 2019 (1719). 
[8] Dohrmann, Gail V. “John Dollar: Marianne Wiggins' Anti-Utopian Novel.” English Journal (Apr 1991): 80, 4; ProQuest Central p. 69.

[9] Fallon, Ann Marie. "Anti-Crusoe, Alternative Crusoes: Revisions of the Island Story in the Twentieth Century." The Cambridge Companion to Robinson Crusoe (2018), 207-220.

[10] Friedman, Susan Stanford. Mappings: Feminism and the Cultural Geographies of Encounter. Princeton , N.J. : Princeton University Press, 1998.

[11] Gandhi, Me Leela. Postcolonial Theory: A critical Introduction. Edinburgh: Edinburgh University Press, 1998.

[12] Golding, William. Lord of the Flies. [Main Edition, Kindle Edition]. London:Faber \& Faber, 2012 (1954).

[13]Gilbert, Sandra and Susan Gubar. No Man's Land: The Place of the Woman Writer in the Twentieth Century. New Haven: Yale University Press, 1988.

[14]Heidegger, Martin. An Introduction to Metaphysics. (Trans. Ralph Manheim.) New York: Anchor Books Press, 1961 (1953).

[15]Hekman S. "The Ontology of Change". Feminist Interpretations of Hans-Georg Gadamer.

(Ed. Lorraine Code.) 2003:181-202.

[16]Hutcheon, Linda. "Beginning to Theorize Postmodernism." Textual Practice (1987): 10-31.

[17]----- The Polities of Postmodernism. London: Routledge, 1986.

[18] Kaplan, Caren. "Deterritorializations: The Rewriting of Home and Exile in Western Feminist Discourse." Cultural Critique 6 (Spring 1987): 187-198.

[19]Lawrence, Karen. Penelope Voyages: Women and Travel in the British Literary Tradition. Ithaca, N.Y.: Cornell University Press, 1994.

[20] Levin, Charles. "Art and the Sociological Ego: Value from a Psychological Perspective." Life after Postmodernism: Essays on Value and Culture. (Ed. John Fekete.) New York: St. Martin's Press, 1987.

[21]Lyotard, Jean-Francois. The Postmodern Condition: A Report on Knowledge. (Trans. Bennington, Geoff and Brian Massumi.) Minneapolis: U of Minnesota P, 1984 (1979).

[22] Miller, Leslie J. "The Poverty of Truth-Seeking: Postmodernism, Discourse Analysis and Critical Feminism."Theory \& Psychology 10.3 (2000): 313352

[23] Novak, Maximillian. Danial Defoe: Master of Fictions. Oxford: Oxford University Press, 1995.

[24] Peterson, Nancy J. "History, Postmodernism, And Louise Erdrich's Tracks." PMLA 109 (1994)
[25] Schrag, Calvin O. Existence and Freedom Towards an Ontology of Human Finitude. Northwestern: Northwestern UP, 1961.

[26] Watt, Ian. The Rise of the Novel. Berkeley: University Of California Press, 1957.

[27] Waugh, Patricia. Feminine Fictions: Revisiting the Postmodern. London: Routledge, 1989.

[28] Wiggins, Marianne. John Dollar. New York: Harper \& Row, 1989.

[29]Zygmunt, Bauman. Postmodern Ethics. Oxford: Blackwell Press, 1993. 